\title{
Monitoring Water Quality Using Biotic Indices of Benthic Macroinvertebrates along Surfaces Water Ecosystems in Some Tourism Areas in East Java, Indonesia
}

\author{
Retno Wimbaningrum ${ }^{1,2^{*}}$, Serafinah Indriyani ${ }^{2}$, Catur Retnaningdyah ${ }^{2}$, \\ Endang Arisoesilaningsih ${ }^{2}$
}

\footnotetext{
${ }^{1}$ Department of Biology, Faculty of Mathematics and Natural Sciences, University of Jember, Jember, Indonesia

${ }^{2}$ Department of Biology, Faculty of Mathematics and Natural Sciences, University of Brawijaya, Malang, Indonesia
}

\begin{abstract}
The research aimed to monitor surface water quality by using water quality index NSF-WQI and accurate biotic index of benthic macroinvertebrate. This study was conducted in September to November 2012 in some water tourism destinations in three regencies, i.e. Jember (three sites), Pasuruan (one site), and Malang (one site), East Java, Indonesia. Each site consisted of three stations (upstream, middlestream and downstream). Reference upstream and middlestream were located in the Meru Betiri National Park (MBNP) Jember. Water quality and benthic macroinvertebrates sampling were conducted in each site. While physical-chemical data consisted of TDS, $\mathrm{DO}, \mathrm{pH}, \mathrm{NO}_{3}-$ N, TP and temperature were analyzed to determine the NSF-WQI index. Macrozoobenthic data were analyzed to determine three diversity indices and 11 biotic indices. Results showed that based on parameter of DO, TP, $\mathrm{NO}_{3}-\mathrm{N}, \mathrm{TDS}$ and $\mathrm{pH}$, water quality in downstreams were generally lower than upstreams. Upstream to middlestreams of two sites in Jember were good to excellent based on NSF-WQI water quality and biotic indices. Therefore, the water were qualified as drinking water resources and also served as safe recreational water. The accurate biotic indices to surface water quality in this study were \% EPT, ASPT, $\mathrm{HBI}, \mathrm{FBI}$ and \% Gastropodes.
\end{abstract}

Keywords: biotic indices, benthic macroinvertebrates, water quality index, water tourisms destination

\section{INTRODUCTION}

Unpolluted surface water is important resources for drinking water, irrigation, industry, farming, recreation, and other usage. However, now days most of the rivers were severelly polluted due to anthropogenic activities [1] and pollution of surface water became crucial environment issue all over the world [2]. Low water quality caused by pollution decrease water availability for directly or indirectly use, including for irrigation [3] or recreational water [4]. Natural process such as decaying, erosion, and flooding as well as anthropogenic activities like urbanization, industry and agriculture are the factors that causing pollution on the surface water [5].

Monitoring activity of river water quality is important to control, manage, and preserve these important natural resources. Ecosystem health of fresh waters determined from its physical, chemical and biological characteristics [6]. Thus monitoring activity of water quality was commonly determined by its physical, chemical, biological qualities [7]. To simplify presentation of monitoring results of water quality, utilization

\footnotetext{
${ }^{*}$ Correspondence address:

Retno Wimbaningrum

Email : wimbaningrumsubagio@gmail.com

Address : Jl. Kalimantan, Sumbersari, Jember Regency, East Java
}

of Water Quality Index (WQI) is more effective. WQI provides single value that express comprehensively water quality on particular site with several water quality parameters and transform complex water quality data into a more easily-understand information and useful for community. Water quality is difficult to comprehend if only based on numerous samples [8].

The results of monitoring on water quality also could be interpreted by biotic indices that determined based on benthic macroinvertebrates data. This organism groups has wide sensitivity range towards changes on habitat and water quality [9]. Benthic macroinverterbrates are important bioindicator that could inform the changes of water quality in a more accurate way compared to physico-chemical and microbiology parameters [10]. The benthic macroinvertebrates have been frequently used for assessing and monitoring water quality using diversity and biotic indices on the level of community structure [10] such as BMWP, ASPT, HBI, FBI and EPT [1217].

Utilization of biotic and diversity indices of benthic macroinvertebrates can be profited to assess feasibility of water resources and impact of human activity on water quality in aquatic ecosystem of tourism area. Moreover these indices can further be used as a basis for 
management recommendations for tourism destination. For these reason, this study aimed to determine the accurate biotic index to assess the water quality in the lotic ecosystem as tourism destination. The ecosystems consisted of springs, waterfall, river, and tertiary irrigation channels.

\section{MATERIALS AND METHODS Study Area}

The research was conducted in the Regency of Jember, Pasuruan and Malang, East Java, Indonesia. Study in Jember was located in three sites, namely Sanenrejo, Panti and Slawu, whereas in Pasuruan and Malang it was located in one site, i.e. Cowek and Lawang, respectively. Each site was divided into three stations, e.g. upstream, midllestream, and downstream. Upstream and middlestream in Sanenrejo are springs and river of Watu Gembuk, which are including in the management of Meru Betiri National Park (MBNP) and profited as reference site. The upstream in Panti is Tancak Waterfall, which its water stream down to the coffee plantation. Middlestream of Panti site is the River of Gunung Pasang. Upstream and middlestream of Slawu is Jompo River, while upstream and middlestream in Pasuruan site is Dam springs and river. Upstream and middlestream of Lawang as well as all downstream in all sites are tertiary irrigation channels (Fig. 1). Data sampling was taken on dry season of September to November 2012.

\section{Water Sampling, in situ Assessment and Water Physico-chemical Analysis}

Water sampling and in situ measurement of physico-chemical parameters were conducted thrice in each station. Water sampling was taken in $1 \mathrm{~L}$ plastic bottle. The bottles of water sample was then stored in a cooler box with temperature $4^{\circ} \mathrm{C}$. Physico-chemical parameters of in situ measurement are including conductivity (EC), $\mathrm{pH}$, dissolved oxygen (DO), temperature. These measurements used CyberScan 600 series meters EUTECH Model PCD 650, HI 98127 pHep ${ }^{\circledR} 4 \mathrm{pH}$. Temperature Tester HANNA, DO meter Lutron Model DO5510 and thermometer. The width of channels or river, depth, and water flow rates were determined on each sampling points.

Water samples were then taken to laboratory to be analyzed. The analysis consisted of nitrogen nitrate $\left(\mathrm{NO}_{3}-\mathrm{N}\right)$, total phosphor (TP) and total dissolved solvent (TDS) refer to Standard Methods for Examination of Water and Waste Water [18]. Data of temperature, $\mathrm{DO}, \mathrm{NO}_{3}-\mathrm{N}, \mathrm{TP}$, and $\mathrm{pH}$ were analyzed to determine the value of National Sanitation Foundation Water Quality Index (NSF-WQI) [19]. Water sample analysis was conducted in the Laboratory of Anorganic Chemical, University of Jember. While benthic macroinver-tebrates were identified in Laboratory of Ecology and Animal Diversity, Brawijaya University and Laboratory of Botany, University of Jember.

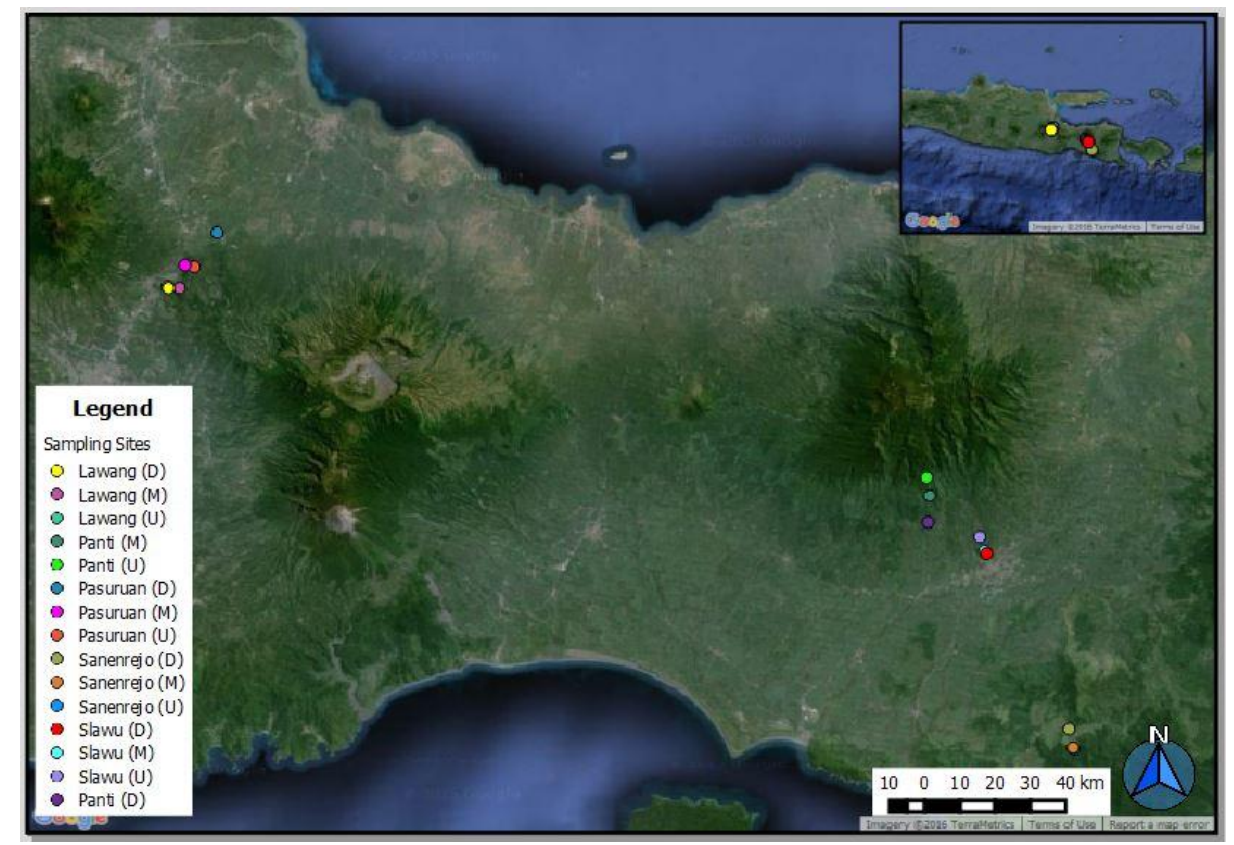

Figure 1. Location Sites in Regency of Jember, Pasuruan and Malang (15 sampling stations in five research sites) 


\section{Sampling, Identification, and Analysis of Benthic Macroinvertebrates Data}

Benthic macroinvertebrates were collected by using Surber net. Surber net was positioned on the bottom of flow with opened part of net against water flow, while net frame attached to the bottom of river. Basal substrates of the river include in the net frame were stirred thus the materials including benthic macroinvertebrates enter the net. Collected materials were poured into plastic container. Using pinset or pipet, benthic macroinvertebrates were seperated from the debris. The number of individu for each taxa was counted and all microscopic specimen were taken for further identification in laboratory. Specimen was stored in bottle contained alcohol $70 \%$ [14]. Each specimen was then identified under microscope to determine the taxa.

Data of benthic macroinvertebrates were analyzed to determine the diversity and biotic indices. Three diversity indices used in this study were Shannon-Wiener $(H)$, Simpson (D) and Margalef $\left(D_{M g}\right)$ [9]. Eleven biotic indices were including EPT (Ephemeroptera Plecoptera Trichoptera), \%EPT, \%Odonata, \%Choronomidae, \%Diptera, \%Gastropoda, Biological Monitoring Working Party (BMWP), Average Score per Taxon (ASPT), Family Biotic Index (FBI), and Hilsenhoff Biotic Index (HBI) [20-24].

\section{Statistical Analysis}

Data of physico-chemical parameter were tested by analysis of variance to compare the average value of each parameter among five sampling sites. Multiple comparison of each parameter among sampling sites was determined by using the Games Howell test ( $p \leq 0.05$ ). Analysis of Pearson correlation was conducted for the value of NSFWQI, diversity index, and biotic index of benthic macroinvertebrates to select accurate indices for the evaluation of surface water quality. All statistical analysis was conducted by using software SPSS 16.

\section{RESULTS AND DISCUSSION \\ Water Physico-Chemical Quality}

Monitoring water physico-chemical quality ( $\mathrm{EC}, \mathrm{DO}, \mathrm{NO}_{3}-\mathrm{N}, \mathrm{TP}, \mathrm{TDS}$ and $\mathrm{pH}$ ) in the research sites were presented in Fig. 2. According to Indonesia Republic Government Regulation No. 82 of 2001 on Management of Water Quality and Water Pollution Control, water of three stations of Sanenrejo and Panti were grouped in the water category of Class I (qualified for drinking water resources). Upstream of Slawu categorized as Class II (qualified for recreational water, fresh water fish farming, livestock farming, and irrigation). Pasuruan, middlestream and downstream of Slawu, and upstream of Lawang categorized in Class III (qualified for fresh water fish farming, livestock farming or irrigation), while middlestream and downstream in Lawang categorized in Class IV (qualified for irrigation); based on its concentration on $\mathrm{DO}, \mathrm{NO}_{3}-\mathrm{N}, \mathrm{TP}$, TDS and $\mathrm{pH}$.

Water of the upstream and middle stream of Sanenrejo and Panti were qualified for drinking water resources, as well as met the requirement for recreational water. Sanenrejo is in the area of Meru Betiri National Park therefore the water quality was protected and undisturbed by waste form anthropogenic activities. Water quality of upstream in Panti where is waterfall of Tancak also was better protected from anthropogenic activities. It is located far from human settlements. Natural process was not significantly affected the concentration of $\mathrm{NO}_{3}-\mathrm{N}, \mathrm{TP}$, and TDS. Previous study mentioned that natural processes and anthropogenic activities were responsible towards the water quality in fresh water ecosystem [25]. These three stations were often visited by tourists for recreational water. Water in Slawu, Pasuruan and Lawang were also meets the requirement for irrigation water (Class II, III, and IV), as well as water in Sanenrejo and Panti.

Water temperature in the study sites ranged $18.8-31.5^{\circ} \mathrm{C}$. The lowest water temperature was recorded in the upstream of Panti, whereas the highest temperature was measured in the middlestream of Slawu. Water temperature is affected by the air temperature, and the air temperature in the upstream of Panti is the lowest $\left(24^{\circ} \mathrm{C}\right)$ because this station is located at the highest elevation ( $851 \mathrm{~m}$ above sea level). Temperature of surface water is generaly ranged $9-30^{\circ} \mathrm{C}$ [26]. Water temperature is essential in the growth, reproduction, and migration of fish and other aquatic organism. It also controls the rate of chemical and biochemical reaction in the water. It is also an important factor that affects water dissolved oxygen (DO) [27].

The range of average concentration of $D O$ in research stations were 1.6-10.77 mg. $\mathrm{L}^{-1}$. Average concentration of DO in the upstream and middlestream of Sanenrejo was not significantly different to the condition in Panti. Average DO concentration in the five stations was higher and significantly different to the other three first sites (Fig. 2). Waters in three stations of Sanenrejo and 
Panti as well as the upstream in Slawu and Pasuruan are capable to support the growth and activities of aquatic organis because its $D O$ value was higher than $4 \mathrm{mg} . \mathrm{L}^{-1}$. Optimal DO for high water quality ranges $4-6 \mathrm{mg} . \mathrm{L}^{-1}[28]$.

The average $\mathrm{pH}$ on the research sites ranged 6.5-7.9 (Fig. 2). The average $\mathrm{pH}$ on the research sites showed similar results to previous study [29]. Water on most of the stations is alkaline, except water of downstream of Slawu and upstream in Pasuruan is acidic (Fig. 2). Alkaline character generally indicates that water contains magnesium and calcium carbonate which imply the photosynthesis and decomposition occurred in the water [30]. Water in the research sites met $\mathrm{pH}$ requirement of aquatic organism. Water with $\mathrm{pH}$ range 6.09-8.45 optimally supports living aquatic organism [31].

Salinity of irrigation water is generally determined by value of EC and TDS. Both parameters describe water potential to raise salinity and soil infiltration [32]. The EC average on all stations ranged $48.6-503 \mu \mathrm{S} . \mathrm{cm}^{-1}$, whereas the concentration of TDS was $84-529 \mathrm{mg} . \mathrm{L}^{-1}$ (Fig. 2). Based on the EC, water from Panti, Slawu, upstream and downstream of Sanenrejo, upstream and middlestream of Pasuruan was categorized as water with low salinity $\left(E C<250 \mu \mathrm{S} . \mathrm{cm}^{-1}\right)$, while other stations were medium salinity (EC: 250-750 $\left.\mu \mathrm{S} . \mathrm{cm}^{-1}\right)$. As the source of water for irrigation, water in all stations were grouped as non degree of restriction on use, because water EC value was less than FAO limit $700 \mu \mathrm{S} . \mathrm{cm}^{-1}$ [32]. Therefore, water from all stations could be used for irrigation without any risk on salinity or infiltration.

Nitrogen and Phosphorus are essentials nutrition for aquatic organism. In the research, the average concentration of $\mathrm{NO}_{3}-\mathrm{N}$ in the water ranged 0.08-4.96 mg. $\mathrm{L}^{-1}$ (Fig. 2). Concentration of $\mathrm{NO}_{3}-\mathrm{N}$ in this study showed similar value with other studies $[4,33,34]$. Water on all stations in this study is included non degree of restriction on use because the $\mathrm{NO}_{3}-\mathrm{N}$ is less than $\mathrm{FAO}$ limit 5 $\mathrm{mg} . \mathrm{L}^{-1}$ [32]. Therefore, water from all stations could be use to irrigate field without any risk to plants growth. Average concentration of TP in all stations showed lower measurement, i.e. 0.0440.369 mg. $\mathrm{L}^{-1}$ (Fig. 2). Concentration of TP in this study showed similar results with other study [34]. Both $\mathrm{NO}_{3}-\mathrm{N}$ and TP concentration indicate nutrient enrichment of waters and potential eutrofication. TP enters to water body as a result of bed rock weathering, organic matter decaying, synthetic fertilizer, industrial and domestic wastes.
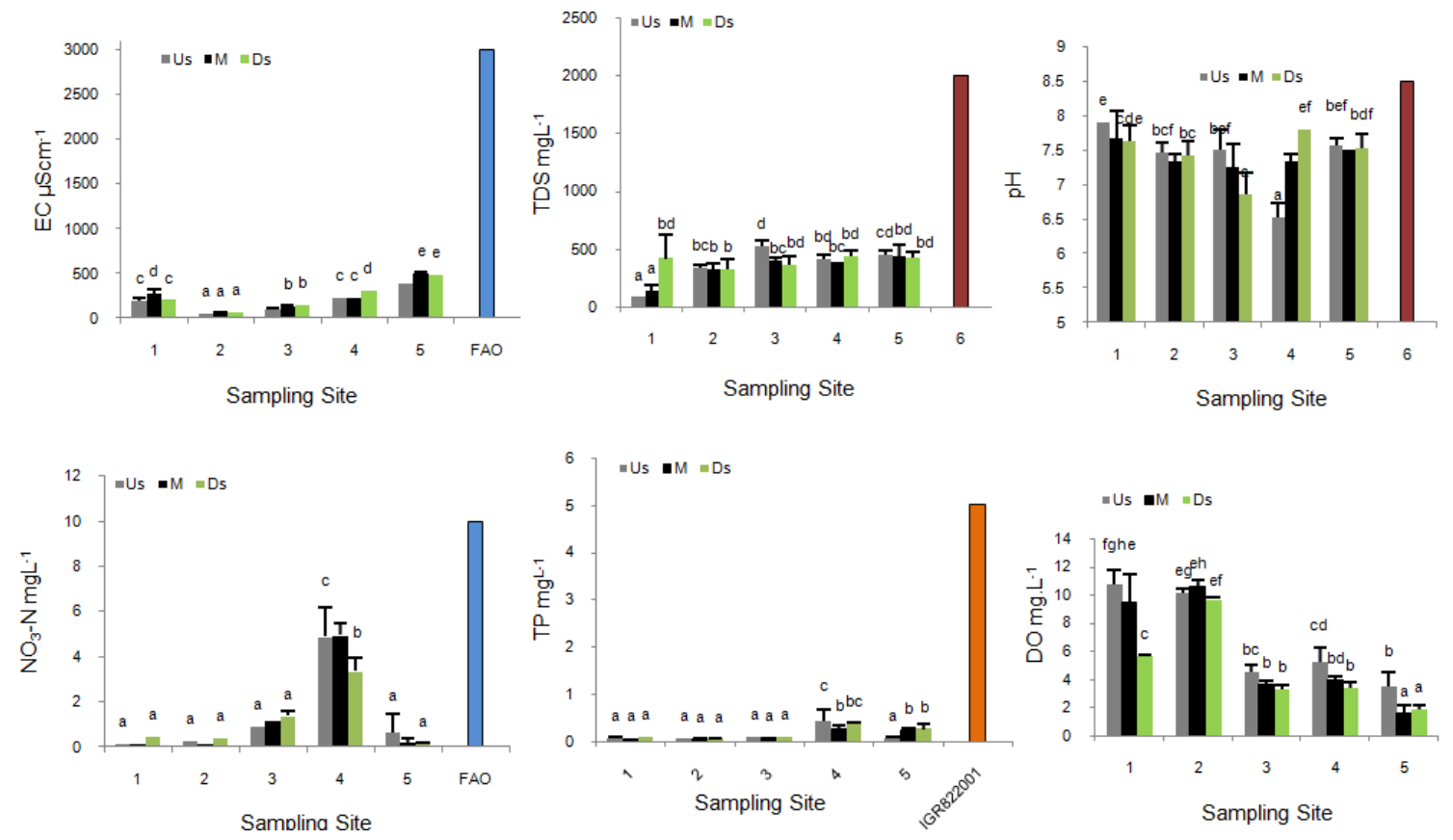

Figure 2. Mean values of $\mathrm{NO}_{3}-\mathrm{N}, \mathrm{TP}, \mathrm{pH}, \mathrm{EC}$, TDS and DO. Magnitude of the bar shows the SD ( $\left.n=3\right)$.

Bars with different letters are significantly different (Games Howell test, $p<0.05$ ). 1=Sanenrejo, 2=Panti, 3=Slawu, 4=Pasuruan, 5=Lawang, 6=FAO (Food and Agricultural Organitation) and IGR82/2001 (Indonesia Government Regulation No. 82 of 2001). 
Based on calculated water quality index NSFWQI, the upstream water in conservation area of Sanenrejo was excellent (blue) quality. While middle stream and downstream in Sanenrejo and three stations in Panti were good (green) quality, while the other stations water were in medium (yellow) quality (Table 1).

Table 1. Variable value of NSF-WQI in the sampling sites

\begin{tabular}{llll}
\hline \multirow{2}{*}{ Location } & \multicolumn{1}{c}{ Station } & $\begin{array}{c}\text { NSF- } \\
\text { WQI }\end{array}$ & $\begin{array}{c}\text { Water Quality } \\
\text { Category }\end{array}$ \\
\hline \multirow{2}{*}{ Sanenrejo } & Upstream & 91.8 & Excellent \\
& Middle stream & 87.2 & Good \\
\multirow{5}{*}{ Panti } & Downstream & 79.9 & Good \\
& Upstream & 81.8 & Good \\
& Middle stream & 82,7 & Good \\
Slawu & Downstream & 82.8 & Good \\
& Upstream & 69.9 & Medium \\
& Middle stream & 68.4 & Medium \\
& Downstream & 69.3 & Medium \\
& Upstream & 64.5 & Medium \\
& Middle stream & 68.3 & Medium \\
& Downstream & 66.5 & Medium \\
& Upstream & 69.6 & Medium \\
& Middle stream & 66.4 & Medium \\
& Downstream & 66.8 & Medium \\
\hline
\end{tabular}

Notes: NSF-WQI = National Sanitation Foundation Water Quality Index

The waters in Sanenrejo and Panti were excellent and good quality, because there was no settlement in its surrounding area, thus no domestic waste entered in the water body. For these reasons the waters of Sanenrejo and Panti, especially the upstream and middlestream, were good resources for drinking water and water recreational location.

Waters in Slawu, Pasuruan and Lawang showed medium quality. Two first sites are located in a middle of settlements, while the last is in a middle of semi-organic paddy field. Both domestic waste and agricultural waste contributed to raise water concentration of TDS, $\mathrm{NO}_{3}-\mathrm{N}$, TP and $\mathrm{pH}$. This medium quality confirmed that the water from Slawu, Pasuruan and Lawang were suitable for irrigation water. It is important notes that utilization of water for those purposes would negatively impact on the people health, crops, or environment quality.

\section{Qualification of Water Quality: Bioindicator of Benthic Macroinvertebrates}

We found 57 taxa of benthic macroinvertebrates which belong to the class of Insecta, Malacostraca, Gastropoda, Bivalvia, Clitella and an unidentified one (Table 2). The Insecta was found as the most (44 taxa) followed by
Gastropoda (10 taxa). The number of taxa in each station varied, the richest was found in the upstream of Pasuruan (31 taxa) and the lowest was in the downstream of Panti (7 taxa). Sensitive taxa of Ephemeroptera, Plecoptera, Trichoptera (EPT) were found mostly in upstream and middlestream of Sanenrejo, Panti, Pasuruan and Lawang. These taxa were found in Slawu except Hydropsyche (Trichoptera) (Table 2). High persentage of EPT taxa was strongly correlated to the good water quality, high concentration of and low nutrient [22]. Therefore, water quality in eight stations where the sensitive taxa found were still in a good quality, even with different level of taxa density and richness. The absent sensitive taxa in Slawu indicated that water quality decreased and affected by anthropogenic activities.

Based on the taxa richness, diversity index of Shannon-Wiener $\left(H^{\prime}\right)$, Simpson (D), ASPT, FBI, HBI and EPT, water in 15 stations showed variable quality (Table 3). It revealed that a station could be qualified into more than a category of water quality. As example, water in the upstream of Sanenrejo classified as fair and good; water in the downstream of Pasuruan categorized as excellent, fair and good quality. Therefore, it is very important to select the accurate biotic and diversity indices to avoid missinterpretation in water quality assessment [24].

In this study, water quality was also determined by using diversity index of ShannonWiener $\left(\mathrm{H}^{\prime}\right)$ and Margalef (D), biotic indices of BMWP, \% EPT, \% Odonata, \% Chironomidae, \% Diptera and \% Gastropoda. However, water quality category could not only be determined by an index, except BMWP. Water quality is considered as good if BMWP is greater than 100 and as very poor if it is less than 10 [35].

Based on index of BMWP, water quality in 14 stations was considered as fair, ranged 11-93, while the downstream water of Lawang was categorized as very poor water quality because the BMWP was less than 10.

Indices of \% EPT, \% Odonata, \% Chironomidae, \% Diptera and \% Gastropoda were presented in Fig. 3. EPT and Odonata are sensitive taxa towards water pollution. If the station has fairly high value for both indices, thus the station is still considered as good quality. Although percentage of EPT and Odonata were not higher than tolerant taxa, the existence of sensitive taxa showed that habitat was less disturbed or there was only a slight disturbance. This condition was found in three station of 
Sanenrejo and Pasuruan, upstream, middle stream of Panti and Slawu. Percentage of tolerant taxa (Diptera) was higher than sensitive taxa (EPT). If percentage of tolerant taxa was high or very high, it indicated polluted water.

In the downstream of Panti, Slawu, Pasuruan and three stations in Lawang, \% Gastropodes showed high percentage $(100 \%$ on downstream of Slawu and more than $50 \%$ on other stations). Whereas \% EPT or Odonata was very low (Fig. 3), therefore the stations were disturbed or polluted. The abundance of EPT taxa was significantly affected by pollutant. Organic pollution was reported to be cause of decreasing abundance of EPT taxa [36, 37].

Determination of accurate diversity and biotic indices for quality of surface water (NSF-WQI) in 15 research stations was conducted by correlation test of Pearson. Correlation test showed that NSF-WQI correlated significantly to \% EPT (0.454), \% Gastropoda (-0.451), ASPT (0.528), FBI $(-0.495)$ and $\mathrm{HBI}(-0.463)$. Index of water quality NSFWQI was positively correlates to \%EPT and ASPT, higher of both values, better water quality was.

Table 2. Spatial distribution of benthic macroinvertebrates in the study sites

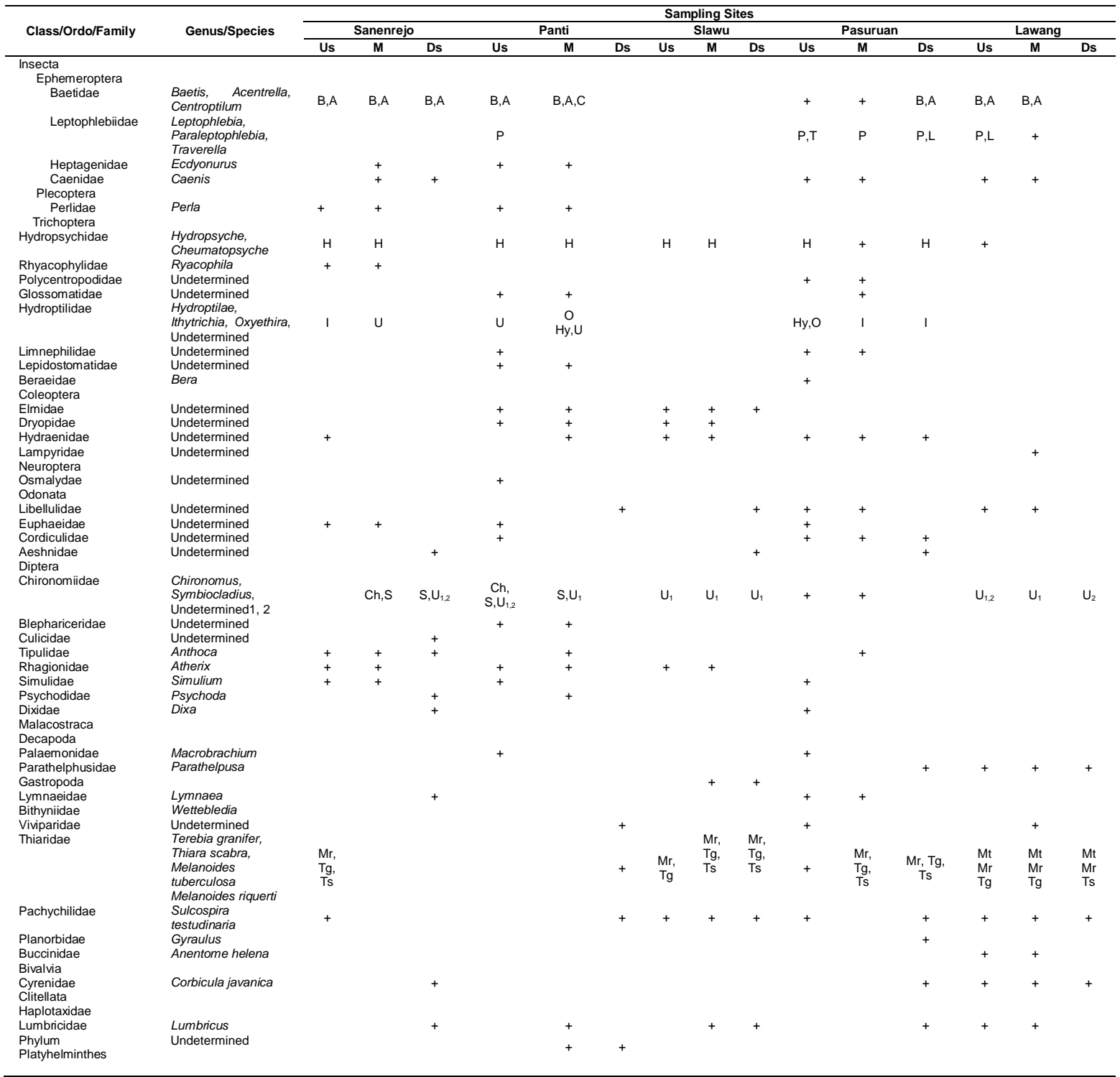

Notes: $\mathrm{B}=$ Baetis; $\mathrm{A}=$ Acentrella $; \mathrm{C}=$ Centroptillum; $\mathrm{P}=$ Paraleptophlebia $; \mathrm{T}=$ Traverella $; \mathrm{L}=$ Leptophlebia $; \mathrm{H}=$ Hydropsyche; $\mathrm{I}=$ Ithytrichia; $\mathrm{O}=$ Oxyethira; $\mathrm{Hy}=$ Hydroptilae; $\mathrm{Ch}=$ Chironomus; $\mathrm{S}=$ Symbiocladius; $\mathrm{Mr}=$ Melanoides riquerti; $\mathrm{Mt}=$ Melanoides tuberculosa; Tg = Terebia granifera; Ts = Thiara scabra; U = Undetermined; Us = Upstream; M = Middle; Ds = Downstream. 
Water Quality of Tourism Areas in Three Regencies of East Java (Wimbaningrum et al)

High NSF-WQI index indicate good water quality. Otherwise, the index of NSF-WQI was negatively correlates to \% Gastropoda, FBI and $\mathrm{HBI}$. Therefore lower \% Gastropoda, FBI and $\mathrm{HBI}$, better water quality was.

Water quality assessment based on the indices of $\mathrm{FBI}$ and $\mathrm{HBI}$ showed that category of water quality in the research stations were excellent (no apparent organic pollution), good (possible slight organic pollution) and fair (significant organic pollution). Based on both biotic indices, 11 stations showed the same water quality, while four other stations were found different water quality, i.e. downstream of Slawu and three stations of Pasuruan (Table 3).

Table 3. Mean values of taxa richness, $\mathrm{H}^{\prime}$ diversity index, D diversity index, ASPT, HBI, FBI and EPT in the study sites

\begin{tabular}{|c|c|c|c|c|c|c|c|c|c|c|}
\hline \multicolumn{2}{|c|}{$\begin{array}{c}\text { Locations/ } \\
\text { Stations }\end{array}$} & \multirow{2}{*}{$\begin{array}{l}\mathrm{D}_{\mathrm{Mg}} \\
2.5\end{array}$} & \multirow{2}{*}{$\begin{array}{c}\text { BMWP } \\
\text { /Water } \\
\text { Quality } \\
47 / F\end{array}$} & \multirow{2}{*}{$\begin{array}{c}\text { TR/ } \\
\text { Water } \\
\text { Quality }\end{array}$} & \multirow{2}{*}{$\begin{array}{c}\mathbf{H}^{\prime} / \text { Water } \\
\text { Quality }\end{array}$} & \multirow{2}{*}{$\begin{array}{c}\text { D/Water } \\
\text { Quality } \\
0.66 \text { / F }\end{array}$} & \multirow{2}{*}{$\begin{array}{c}\begin{array}{c}\text { ASPT/Water } \\
\text { Quality }\end{array} \\
5.88 / G\end{array}$} & \multirow{2}{*}{$\begin{array}{c}\text { FBI/Water } \\
\text { Quality } \\
5.05 \text { / G }\end{array}$} & \multirow{2}{*}{$\begin{array}{c}\text { HBI/ } \\
\text { Water } \\
\text { Quality }\end{array}$} & \multirow{2}{*}{$\begin{array}{c}\text { EPT/ } \\
\text { Water } \\
\text { Quality }\end{array}$} \\
\hline Sanen- & Us & & & & & & & & & \\
\hline rejo & $M$ & 3.4 & $61 / F$ & $18 / F$ & $2.5 / E$ & $0.89 / \mathrm{E}$ & $6.10 / E$ & $5.32 / \mathrm{G}$ & $5.53 / \mathrm{G}$ & $8 / G$ \\
\hline \multirow{2}{*}{ Panti } & $M$ & 4.1 & $67 / F$ & $22 / G$ & $2.6 / E$ & $0.88 / E$ & $5.80 / \mathrm{G}$ & $3.78 / E$ & $4.17 / E$ & $12 / E$ \\
\hline & Ds & 1.2 & $11 / F$ & $7 / \mathrm{VP}$ & $1.6 / \mathrm{G}$ & $0.77 / G$ & $5.50 / \mathrm{G}$ & $7.02 / F$ & $6.96 / F$ & $0 / \mathrm{VP}$ \\
\hline \multirow[t]{3}{*}{ Slawu } & Us & 2.0 & $35 / F$ & 10 / VP & $2.0 / \mathrm{G}$ & $0.89 / \mathrm{E}$ & $5.00 / F$ & $4.66 / \mathrm{G}$ & $4.81 / \mathrm{G}$ & $1 / V P$ \\
\hline & $M$ & 2.5 & $36 / F$ & $13 / F$ & $2.2 / E$ & $0.87 / E$ & $4.50 / F$ & 4.74 / G & $4.86 / \mathrm{G}$ & $1 / \mathrm{VP}$ \\
\hline & Ds & 2.4 & $32 / F$ & $12 / F$ & $2.3 / \mathrm{E}$ & $0.89 / \mathrm{E}$ & $4.57 / F$ & $5.88 / F$ & $5.83 / \mathrm{G}$ & $1 / \mathrm{VP}$ \\
\hline \multirow{2}{*}{ Malang } & $M$ & 3.5 & $36 / F$ & $18 / F$ & $2.1 / E$ & 0.79 / G & 5.14 / G & $6.51 / F$ & $6.6 / F$ & $6 / G$ \\
\hline & Ds & 1.2 & $2 / F$ & 7 / VP & $1.5 / F$ & $0.73 / \mathrm{G}$ & 2.00 / VP & $7.16 / F$ & $7.16 / F$ & $0 / \mathrm{VP}$ \\
\hline \multicolumn{11}{|c|}{ Water Quality Category: } \\
\hline \multicolumn{4}{|c|}{ Excellent (E) } & $>30$ & $>2$ & $1-0.8$ & $>6$ & $0-3.75$ & $0-3.50$ & $>10$ \\
\hline & & $\operatorname{od}(G)$ & $>100$ & $21-30$ & $2-1.6$ & $0.70-0.79$ & $5.1-6.0$ & $3.76-5.37$ & 3.51-5.99 & $6-10$ \\
\hline & & Fair (F) & $10-100$ & $11-20$ & $1.5-1.0$ & $0.60-0.69$ & $4.0-5.0$ & $5.38-7.25$ & $6.01-8.5$ & $2-5$ \\
\hline & ery & $\operatorname{or}(\mathrm{VP})$ & $<10$ & $0-10$ & $<1$ & $<0.6$ & $<4$ & $7.26-10$ & $8.51-10$ & $0-1$ \\
\hline
\end{tabular}

Notes: Us, M, Ds = upstream, middle stream, downstream;

ASPT = Average Score per Taxon; BMWP = Biological Monitoring Working Party; $\mathrm{D}_{\mathrm{Mg}}=$ Margalef diversity index; $\mathrm{D}$ Simpson diversity index; EPT = Ephemeroptera, Plecoptera, Trichoptera; $\mathrm{H}^{\prime}$ = Shannon-Wiener diversity index; FBI = Family Biotic Index; $\mathrm{HBI}=$ Hilsenhoff Biotic Index; $\mathrm{TR}=$ taxa richness

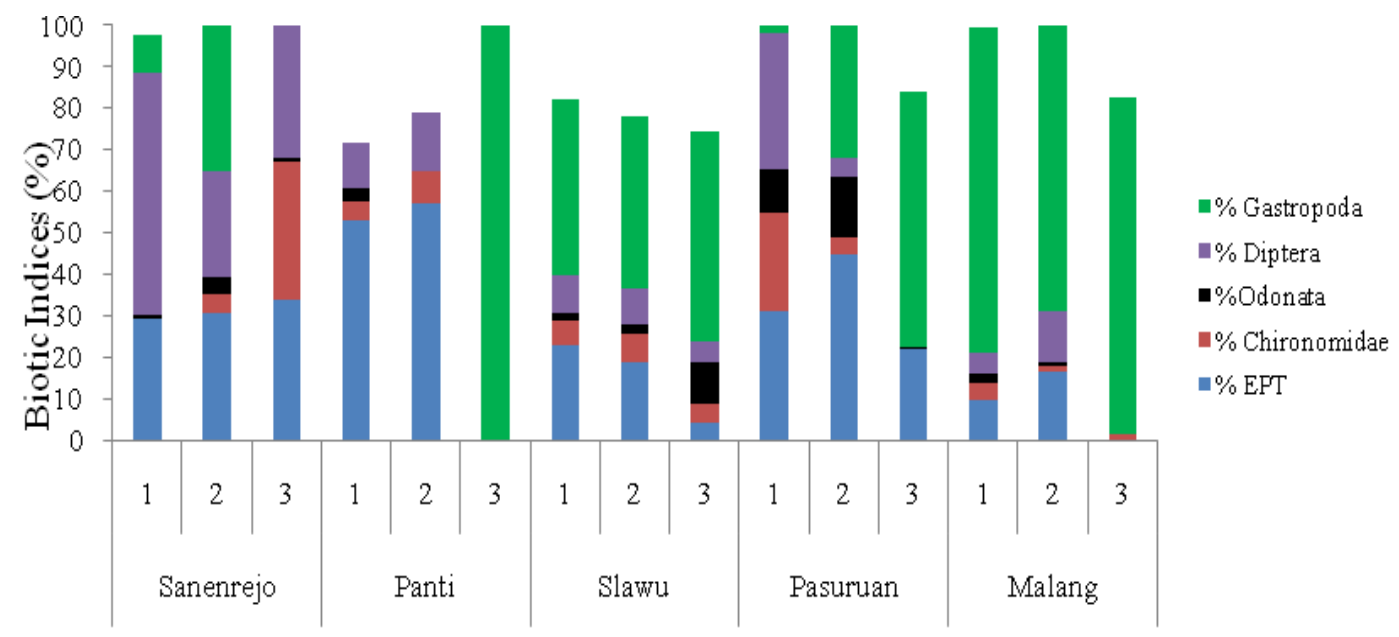

Sampling Site

Figure 3. Mean value of \% EPT, \% Odonata, \% Dptera, \% Chironomidae and \% Gastropoda Indices Notes: 1,2,3 = upstream, middle stream, downstream 
Category of water quality based on ASPT index consisted of excellent, good, fair and very poor. Water assessment in the upstream of Sanenrejo and Panti using indices of ASPT, FBI and $\mathrm{HBI}$ proved the similar conclusion (Table 3 ). This different accuracy among indices was found due to each index gave a particular tolerant score for each taxa. Besides that, not all taxa had been already fixed their tolerant score and included into calculation of biotic index. Three biotic indices grouped the upstream and middlestream of Sanenrejo and upstream of Panti as excellent and good quality respectively. Thus this conclusion was still consistent to the assessment of NSF-WQI and Indonesia Government regulation.

This research results proved that some biotic indices of benthic macroinvertebrates could be used for monitoring impact of human activity on water quality in the tourism area. This evaluation could then be served as a basis for management recommendations of recreational water in tourism area.

\section{CONCLUSION}

Based on monitoring on the physico-chemical characters and biotic quality of surface water in research sites and refer to Indonesia Regulation Government No. 82 of 2001 we concluded as follows: Water in Sanenrejo and Panti was in class I (for drinking water), upstream of Slawu is class II (for recreational water, fresh water fish pond, livestock farming, and irrigation), Pasuruan and upstream of Lawang is class III (for fresh water fish pond, livestock farming, and irrigation), middle stream and downstream of Lawang is class IV (for irrigation). Water quality based on the NSF-WQI showed that water in upstream of Sanenrejo was excellent. Moreover, water of middle stream and downstream of Sanenerejo and three stations of Panti was good, while the other nine stations were medium. Therefore, the water in Sanenrejo and Panti were qualified as drinking water and also used as recreational water especially the springs and river of Watu Gembuk, and Tancak Waterfall. Water in all research sites also met the requirement of irrigation water. Relevant Biotic indices that appropriate to assess the quality of springs, waterfall, river, and irrigation channels are $\mathrm{HBI}, \mathrm{FBI}, \mathrm{ASPT}$ \% EPT and \% Gastropoda. Category of water quality in the research stations based on the indexes of $\mathrm{FBI}$ and $\mathrm{HBI}$ consisted of excellent (no apparent organic pollution), good (possible slightorganic pollution) and fair (significant organic pollution). Based on index of ASPT, water quality was qualified into excellent, good, fair and very poor.

\section{Acknowledgement}

The authors would like to thanks the Directorate of Higher Education, Ministry of Reseacrh and Technology, and Higher Education of Indonesia for the research and doctoral funding (BPDN scholarship). We also thank Yogi Ali Afendi, SSi., Ika Agus Rini, SSi., Condro Wisnu SSi., Viki Vidayanti SSi., Abdul Rasyid SSi., Imam Syafii, Purnomo, SSi., Budiman MSi., Mr. Sobari and Mr. Antok for the assistance in data sampling.

\section{REFERENCES}

[1] Altansukh, O. and G. Davaa. 2011. Application of index analysis to evaluate the water quality of the Tuul River in Mongolia. Journal of Water Resource and Protection 3, 398-414.

[2] Salah, E. A. M., A. M. Turki and E. M. AlOthman. 2012. Assessment of water quality of Euphrates River using cluster analysis. Journal of Environmental Protection 3, 1629 $-1633$.

[3] Simsek, C. and O. Gunduz. 2007. IWQ index: a GIS-integrated technique to assess irrigation water quality. Journal of Environmental Monitoring and Assessment 128, 277-300.

[4] Şen, F. and A. Aksoy. 2015. Chemical and physical quality criteria of Bulakbaşi Stream in Turkey and usage of drinking, fisheries, and irrigation. Journal of Chemistry 2015, 18.

[5] Carpenter, S. R., N. F. Caraco, D. L. Correll, R. W. Howarth, A. N. Sharpley, V. H. Smith. 1998. Nonpoint pollution of surface waters with phosphorus and nitrogen. Ecological Applications 8(3), 559-568.

[6] Venkatesharaju, K., P. Ravikumar, R. K. Somashekar and K. L. Prakash. 2010. Physico-chemical and bacteriological investigation on the River Cauvery of Kollegal Stretch in Karnataka. Journal of Science Engineering and Technology 6 (1), 50-59.

[7] Tyagi S., B. Sharma, P. Singh and R. Dobhal. 2013. Water quality assessment in terms of water quality index. American Journal of Water Resources 1(3), 34-38.

[8] Behmanesh, A. and Y. Feizabadi. 2013. Water quality index of Babolrood River in Mazandaran, Iran. International Journal of 
Agriculture and Crop Sciences 5 (19), 22852292.

[9] Abel, P. D. 1989. Water Pollution Biology. John Wiley and Sons. New York.

[10] Ikromi, R. B. F., O. Arimoro and O. K. Odihirin. 2005. Composition, distribution and abundance of macroinvertebrates of the upper reaches of River Ethiope Delta State, Nigeria. The Zoologies 3, 68-81.

[11] Rosenberg, D. M. and V. H. Resh. 1993. Freshwater Biomonitoring and Benthic Macroinvertebrates. Chapman and Hall. New York.

[12] Moskova, G, R. Soufi and Y. Uzunov. 2008. Application of the EPT-index for ecological status assessment of the river water bodies within the basin of Kamchia River. Bioautomation 11, 73-79.

[13] Gonçalves, F. B. and M. S. Menezes. 2011. A comparative analysis of biotic indices that uses macroinvertebrates to assess water quality in a coastal river of Parana State, Southern Brazil. Biota Neotropica 11(4), 1 10.

[14] Kalyoncu, H. and M. Zeybek. 2011. An application of different biotic and diversity indices for assessing water quality: A case study in the Rivers Çukurca and Isparta (Turkey). African Journal of Agricultural Research 6 (1), 19-27.

[15] Zeybek, M., H. Kalyoncu, B. Karakaş and S. Özgül. 2014. The use of BMWP and ASPT indices for evaluation of water quality according to macroinvertebrates in Değirmendere Stream (Isparta, Turkey). Turkish Journal of Zoology 38, 603-613.

[16] Tan, K. W. and W. C. Beh. 2015. Water quality monitoring using biological indicators in Cameron Highlands Malaysia. Journal Sustainable Development 8(3), 28-42.

[17] Retnaningdyah, C. and E. Arisoesilaningsih. 2014. Indication of Pollution in Some Springs Located in Upstream of Brantas Watersheds Using Benthic Macroinvertebrates Biotic Indices. Proceedings of Biodiversity National Seminar UNS Solo 3(1), 210-213

[18] Clesceri, L. S., A. E., Greenberg and A.D. Eaton. 1998. Standard Methods for the Examintaion of Water and Waste Water, $20^{\text {th }}$ Ed. American Public Health Association, American Water Works Association, and Water Environment Federation. Washington.
[19] Abbasi, S. A. 2002. Water quality indices. State of the Art, Pondicherry University. Centre for Pollution Control and Energy Technology. Pondicherry.

[20] Lenat, D. R. 1988. Water quality assessment using a qualitative collection method for benthic macroinvertebrates. Journal of North American Benthological Society 7, 222-233.

[21] Plafkin, J. L., M. T. Barbour, K. D. Porter, S. K. Gross and R. M. Hughes 1989. Rapid Bioassessment protocols for use in stream and rivers: benthic macroinvertebrates and fish. U.S. Environmental Protection Agency. EPA 440/4-89/001. 8 chapters. Appendices A-D.

[22] Barbour, M. T., J. Gerritsen, B. D. Synder and J. B. Stribling. 1999. Rapid bioassessment protocols for use in streams and Wadeabele Rivers: periphyton, benthic macroinvertebrates, and fish, $2^{\text {nd }} E d$. EPA 841-B-99-002. U.S.Environmental Protection Agency. Washington, D.C.

[23] Mackie, G. L. 2001. Applied aquatic ecosystem concepts. Kendall/Hunt Publishing Company. Dubuque.

[24] Mandavilles, S. M. 2002. Benthic macroinvertebrates in freshwater-taxa tolerance values, metric and protocols. Soil and Water Conservation Society of Metro Halifax. New York.

[25] Samsudin, M. S., H. Juahir, S. M. Zain and N. H. Adnan. 2011. Surface river water quality interpretation using environmetric techniques: case study at Perlis River Basin, Malaysia. International Journal of Environment and Pollution 1(5), 1-8.

[26] Chapman D. and V. Kimstach. 1996. Selection of water quality. In: Chapman D. (Ed). Water Quality Assessment - A Guide Use Biota, Sediments, and Water in Environmental Monitoring, $2^{\text {nd }} E d$. UNESCO/WHO/ UNEP.

[27] Shah, A. and G. S. Joshi. 2015. Evaluation of water quality index for River Sabarmati, Gujarat. Applied Water Science 7, 1-10.

[28] De, A. K. 2003. Environmental chemistry, $5^{\text {th }}$ Ed. New Age International Publisher. New Delhi.

[29] Aris, A. Z., W. Y. Lim, S. M. Praveena, M. K. Yusoff, M. F. Ramli and H. Juahir. 2014. Water quality status of selected rivers in Kota Marudu, Sabah, Malaysia and its suitability for usage. Sains Malaysiana 43(3), 377-388. 
[30] Mokhtar, M. B., A. Z. Aris, M. H. Abdullah, M. K. Yusoff, M. P. Abdullah, A.R Idris and R. I. Raja Uzir. 2009. A pristine environment and water quality in perspective: Maliau Basin, Borneo's mysterious world. Water and Environment Journal 23(3), 219-228.

[31] Boyd, C. E. and Lichtkoppler. 1979. Water quality management in pond fish culturing. Research and Development Series No. 22. Auburn University. Alabama.

[32] Ayers, R. S. and Westot, D. W. 1994. Water quality for agriculture. FAO Irrigation and Drainage Paper. 29 Rev 1.

[33] Binkley, D., G. G. Ice, J. Kaye and C. A. Williams. 2004. Nitrogen and phosphorus concentrations in forest streams of The United States. Journal of the American Water Resources Association 40(5), 12771291.

[34] Effendi, H., Y. Romanto, Wardiatno. 2015. Water quality status of Ciambulawung River, Banten Province, based on pollution index and NSF-WQI. Procedia Environmental Sciences 24, $228-237$.

[35] Mason, C. F. 2002. Biology of Freshwater Pollution, $4^{\text {th }}$ Ed. Prentice Hall. New York.

[36] McCabe, D. J. and N. J. Gotelli. 2000. Effects of disturbance frequency, intensity, and area on assemblages of stream macroinvertebrates. Oecologia 124, 270-279.

[37] Kartikasari, D., C. Retnaningdyah, E. Arisoesilaningsih. 2013. Application of Water Quality and Ecology Indices of Benthic Macroinvertebrate to Evaluate Water Quality of Tertiary Irrigation in Malang District. The Journal of Tropical Life Science 3(3), 193-201. 